\title{
EFEK PUPUK CAIR KALSIUM TERHADAP PERTUMBUHAN DAN PRODUKSI TANAMAN KENTANG (SOLANUM TUBEROSUM L.)
}

\author{
Donatus Dahang ${ }^{1)}$, Rafael Remit Winardi' ${ }^{2}$, Muhammad R.R. Lubis ${ }^{3)}$ \\ ${ }^{122) 3)}$ Universitas Quality, Jln. Ngumban Surbakti N0. 18 Medan, Sumatera Utara \\ Email : Donates.tarsier.project@gmail.com
}

\begin{abstract}
ABSTRAK
Penelitian Efek Pupuk Cair Kalsium Terhadap Pertumbuhan dan Produksi Tanaman Kentang (Solanum tuberosum L.) telah dilaksanakan dengan baik. Penelitian tersebut dilakukan di Desa Lau Gumba, Kecamatan Berastagi, Kabupaten Karo, Sumatera Utara, terhitung Desember 2018 - Mei 2019. Penelitian ini menggunakan Rancangan Acak Kelompok (RAK) Faktorial yang terdiri dari dua faktor perlakuan, yaitu Faktor I konsentrasi pupuk cair kalsium "BF" (B) empat taraf; B0 : kontrol, B1 : 2,5 ml/96 ml air, B2 : $5 \mathrm{ml} / 96 \mathrm{ml}$ air, dan B3 : $7.5 \mathrm{ml} / 96 \mathrm{ml}$ air. Faktor II konsentrasi pupuk cair kalsium "BC" (C) empat taraf; C0 : kontrol, C1 : $1 \mathrm{ml} / 96 \mathrm{ml}$ air, C2 : $2 \mathrm{ml} / 96 \mathrm{ml}$ air, dan C3 : $3 \mathrm{ml} / 96 \mathrm{ml}$ air. Hasil penelitian menunjukkan, perlakuan konsentrasi pupuk cair kalsium berpengaruh nyata $(\mathrm{p}<0.05)$ terhadap tinggi tanaman dan berat umbi. Pupuk yang berpengaruh pada tinggi tanaman yaitu "BF" (B) dan "BC" (C) dengan konsentrasi B3 (7,5 ml/96 ml air) dan C3 (3 ml/96 ml air) dengan nilai tertinggi 39.4, dan pupuk yang berpengaruh pada berat umbi adalah "BF" (B) dan "BC" (C) yaitu konsentrasi B3 (7,5 ml/96 ml air) dan C3 (3 ml/96 ml air). Pada parameter ukuran umbi pupuk yang berpengaruh adalah pupuk "BF" (B) dengan konsentrasi B1 $<3 \mathrm{~cm}(2,5 \mathrm{ml} / 96 \mathrm{ml}$ air $)$.
\end{abstract}

Kata kunci : kentang, pupuk cair kalsium, pertumbuhan, produksi

\begin{abstract}
The research effects of liquid calcium fertilizers on the growing and producing of potatoes (Solanum tuberosum L.) had properly done. The research was carried out on Lau Gumba Village, Berastagi Sub-district, Karo Regency, North Sumatra, December 2018- May 2019. Randomize Block Design with two factors i.e. Faktor I: Concentration of "BF" fertilizer, B0: control, B1: 2, $5 \mathrm{ml} / 96 \mathrm{ml}$ of water, B2: 5 $\mathrm{ml} / 96 \mathrm{ml}$ of water, B3: 7, $5 \mathrm{ml} / 96 \mathrm{ml}$ of water. Factor II: concentration of "BC" fertilizer, C0: control, C1: $1 \mathrm{ml} 96 \mathrm{ml}$ of water, C2: $2 \mathrm{ml} 96 \mathrm{ml}$ of water, C3: 3 $\mathrm{ml} 96 \mathrm{ml}$ of water. The results of the study show that the concentration of the liquid calcium fertilizer had significantly impact $(p<0.05)$ to the growing and the production of tubers. The concentration of B3 (7,5 ml/96 ml of water) and C3 (3 $\mathrm{ml} / 96 \mathrm{ml}$ of water) had highest score $39.4 \mathrm{~cm}$ of plants' height, The concentration of $\mathrm{B} 3(7,5 \mathrm{ml} / 96 \mathrm{ml}$ of water) and $\mathrm{C} 3(3 \mathrm{ml} / 96 \mathrm{ml}$ of water $)$ had significant impact to tubers' weight.
\end{abstract}

Key Words: potatoes, calcium liquid fertilizers, growing, production 


\section{Latar Belakang}

Berbagai tanaman hortikultura, tanaman perkebunan, tanaman pangan dan ternak dihasilkan di lahan pegunungan. Kentang (Solanum tuberosum L.) adalah salah satu jenis tanaman sayuran yang banyak ditanam di daerah pegunungan. Bahkan, terdapat varietas kentang tertentu yang tumbuh dengan baik pada dataran menengah berkisar $300-700 \mathrm{~m}$ dpl. Kentang termasuk salah satu tanaman yang bernilai ekonomi tinggi sehingga banyak petani ataupun investor menanamkan modal untuk membudidayakan tanaman kentang (Samadi, 2007). Tidak heran kentang berperanan penting dan diprioritas untuk dikembangkan dan berpotensi dalam diversifikasi pangan.

Kentang sangat ideal ditanam di daerah pegunungan pada ketinggian lebih dari $1.000 \mathrm{~m}$ dpl. Namun hingga kini produktivitas kentang masih terbatas, sehingga masih dibutuhkan tindakan untuk meningkatkan produktivitasnya. Hal tersebut antara lain disebabkan oleh penggunaan bibit kurang bermutu, pengelolaan budidaya yang belum optimal serta penanganan pascapanen yang belum memadai (Effendi, 2004).

Salah satu tindakan budidaya yang dibenahi agar produktivitas kentang meningkat adalah penanganan pemupukan. Pemupukan merupakan salah faktor penting untuk meningkatkan produksi. Pemupukan bahkan dianggap sebagai faktor dominan dalam produksi pertanian. Melalui pemupukan yang tepat maka diperoleh keseimbangan unsur hara enssensial yang dibutuhkan tanaman (Effendi, 2004).

Di kalangan petani kentang, ketergantungan dalam menggunakan pupuk kimia sintetis hampir mencapai $100 \%$, sedangkan penggunaan pupuk organik masih kurang (Herman, 2000). Penggunaan pupuk kimia sintetis yang berlebihan dapat menyebabkan pencemaran lingkungan, apalagi penggunaan secara terus menerus dalam waktu lama dapat menyebabkan produktivitas lahan menurun dan mikroorganisme penyubur tanah berkurang (Susi, 2009). Dekkers \& van der Werff (2001) menambahkan, penggunaan pupuk sintetis yang tinggi pada tanah dapat mendorong hilangnya hara, polusi lingkungan, dan rusaknya kondisi alam. Pemberian pupuk organik cair harus memperhatikan konsentrasi atau konsentrasi yang diaplikasikan terhadap tanaman. Dari beberapa penelitian menunjukkan bahwa pemberian pupuk organik cair melalui daun memberikan pertumbuhan dan hasil tanaman yang lebih baik dari pada pemberian melalui tanah (Hanolo, 1997).

Pemberian pupuk dapat dilakukan melalui tubuh tanaman atau dikenal dengan istilah pupuk daun. Kelebihan yang diperoleh dari pemberian pupuk melalui daun adalah pupuk daun umumnya mengandung unsur hara yang lengkap terdiri atas unsur makro dan unsur mikro, unsur hara lebih cepat larut sehingga cepat diserap tanaman (Anonim, 1989). Lebih lanjut, kelebihan pupuk cair adalah unsur hara yang dikandungnya lebih cepat tersedia dan mudah diserap tanaman. Selain dengan cara disiramkan pupuk cair dapat digunakan langsung dengan cara disemprotkan pada daun atau batang tanaman (Pardosi, dkk, 2014). Sebelum di semprotkan, umumnya pupuk daun perlu diencerkan dengan konsentrasi tertentu sesuai konsentrasi yang dianjurkan (Lingga dan Marsono, 2005).

Pengunaan pupuk buatan dewasa ini terus meningkat sebagai dampak meningkatnya produktivitas pupuk tersebut. Beberapa jenis pupuk cair buatan adalah pupuk cair calcium "BF" dan "BC" yang mengandung unsur hara makro dan mikro. Kedua pupuk cair ini berguna untuk memberikan unsur hara kepada tanaman kentang agar dapat tumbuh lebih baik, khususnya untuk pertumbuhan vegetatif. Pada penelitian 
ini pemberian pupuk dilakukan dengan cara disemprotkan pada daun dan batang tanaman secara merata.

\section{Tujuan Penelitian}

1. Untuk mengetahui pengaruh positif dari pupuk cair kalsium "BF" dan "BC" terhadap pertumbuhan dan produksi tanaman kentang (Solanum tuberosum L.)

2. Untuk mengetahui konsentrasi pupuk cair kalsium yang tepat untuk pertumbuhan dan produksi tanaman kentang (Solanum tuberosum L.)

\section{Metodologi}

Penelitian ini dilaksanakan di Desa Laugumba, Kecamatan Berastagi, Kabupaten Karo, Provinsi Sumatera Utara, terhitung Desember 2018 hingga Mei 2019. Penelitian ini menggunakan rancangan acak kelompok pola faktorial, pupuk cair kalsium "BF" (B), 4 taraf: $\mathrm{B}_{0}$ $=0$ (kontrol), $\mathrm{B}_{1}=2,5 \mathrm{ml} / 96 \mathrm{ml}$ air, $\mathrm{B}_{2}$ $=5 \mathrm{ml} / 96 \mathrm{ml}$ air, dan $\mathrm{B}_{3}=7,5 \mathrm{ml} / 96 \mathrm{ml}$ air, dan pupuk cair kalsium "BC" (C), 4 taraf: $\mathrm{C}_{0}=0$ (Kontrol), $\mathrm{C}_{1}=1 \mathrm{ml} / 96 \mathrm{ml}$ air, $\mathrm{C}_{2}=2 \mathrm{ml} / 96 \mathrm{ml}$ air, dan $\mathrm{C}_{3}=3 \mathrm{ml} /$ $96 \mathrm{ml}$ air.

Data penelitian ini dianalisis dengan program SPSS 23 sesuai dengan model analisa data yang digunakan pada Rancangan Acak Kelompok (RAK) yaitu:

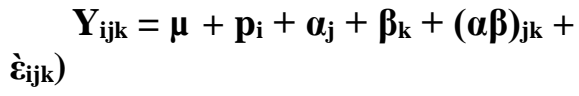

$\mathrm{Y}_{\mathrm{ijk}}$ (hasil pengamatan pada ulangan pada taraf ke-i yang diberi perlakuan konsentrasi pupuk cair kalsium "BF" pada taraf ke-j dan yang diberi perlakuan konsentrasi pupuk cair kalsium "BC" pada taraf ke-k, $\mu$ (ratarata nilai tengah perlakuan, $p_{i}$ (pengaruh ulangan pada taraf ke-i), $\alpha_{\mathrm{j}}$ (pengaruh dari perlakuan konsentrasi pupuk cair kalsium "BF" pada taraf ke-j), $\beta_{\mathrm{k}}$ (Pengaruh perlakuan konsentrasi pupuk cair kalsium) "BC" pada taraf ke-k, $(\alpha \beta)_{\mathrm{jk}} \quad$ (pengaruh interaksi dari konsentrasi pupuk cair kalsium "BF" pada taraf ke-j dan konsentrasi pupuk cair kalsium "BC" pada taraf ke-k, dan $\grave{\varepsilon}_{\mathrm{ijk}}$ (pengaruh galat dari konsentrasi pupuk cair kalsium "BF" pada taraf ke-j dan konsentrasi pupuk cair kalsium "BC" pada taraf ke-k dalam ulangan pada taraf ke-i)

\section{Hasil}

Setelah dilakukan pengamatan terhadap ketinggian tanaman dan berat umbi, maka diperoleh hasil sebagai berikut:

\section{Tinggi Tanaman}

Hasil analisis data menunjukkan, terdapat pengaruh yang sangat signifikan variavel konsentrasi pupuk kalsium "BF" (B) dan pupuk "BC" (C) terhadap pertumbuhan tinggi tanaman kentang dan sebaliknya variabel jenis pupuk tidak signifikan. Hasil uji Duncan yang disajikan pada Tabel 1 .

Tabel 1. Rata-Rata Pertambahan Tinggi Tanaman $(\mathrm{cm})$ Kentang Pengaruh Pupuk Cair "BF" (B)

\begin{tabular}{|c|c|c|c|c|c|c|c|c|c|}
\hline Per & $2 \mathrm{mst}$ & $2 \mathrm{mst}$ & $4 \mathrm{mst}$ & $=$ & $6 \mathrm{mst}$ & st & t & it & $\begin{array}{c}10 \\
\text { mst }\end{array}$ \\
\hline $\begin{array}{l}\text { B0 } \\
\text { (kontrol) }\end{array}$ & & & & $d$ & $d$ & 31 & $f$ & 53. & $1.73 \mathrm{e}$ \\
\hline $\mathrm{ml} / \mathrm{L}$ ) & $10.65 \mathrm{a}$ & $13.23 \mathrm{a}$ & $18.55 \mathrm{a}$ & $24.78 \mathrm{a}$ & $30.2 \mathrm{a}$ & $40.4 \mathrm{a}$ & $47.25 \mathrm{~b}$ & $53.93 \mathrm{a}$ & $58.45 \mathrm{a}$ \\
\hline
\end{tabular}




\begin{tabular}{lccccccccc}
\hline $\begin{array}{l}\mathrm{B} 2(5 \\
\mathrm{ml} / \mathrm{L})\end{array}$ & $11.58 \mathrm{a}$ & $14.48 \mathrm{~b}$ & $19.75 \mathrm{a}$ & $26.38 \mathrm{a}$ & $31.9 \mathrm{a}$ & $41.58 \mathrm{a}$ & $48.8 \mathrm{a}$ & $56.13 \mathrm{a}$ & $60.25 \mathrm{a}$ \\
$\mathrm{B} 3(7,5$ & & & & & & & & & \\
$\mathrm{ml} / \mathrm{L})$ & $12.48 \mathrm{a}$ & $16.33 \mathrm{a}$ & $21.73 \mathrm{a}$ & $27.65 \mathrm{a}$ & $32.73 \mathrm{a}$ & $42.95 \mathrm{a}$ & $47.08 \mathrm{a}$ & $55.8 \mathrm{a}$ & $60.28 \mathrm{a}$ \\
\hline *Angka yang dikuti oleh huruf yang sama menunjukkan berbeda tidak nyata
\end{tabular}

Tabel 1. menunjukkan, penggunaan pupuk "BF" berbeda sangat nyata dengan kontrol. Semenjak minggu kedua sampai ke sepuluh tinggi tanaman kontrol (B0) berpengaruh nyata dengan B1, B2, dan B3. Diantar konsentrasi

"BF" hingga tanaman berumur $5 \mathrm{mst}$ tidak terdapat perbedaan signifikan pertumbuhan tanaman kentang, dan 6 mst sampai 10 mst terdapat perbedaan pertumbuhan pada B1 $(2,5 \mathrm{ml} / \mathrm{L})$ dengan B2 $(5 \mathrm{ml} / \mathrm{L})$ dan B3 $(7,5 \mathrm{ml} / \mathrm{L})$.

Tabel 2. Rata-Rata Pertambahan Tinggi Tanaman (cm) Kentang Pengaruh Pupuk Cair "BC"(C)

\begin{tabular}{|c|c|c|c|c|c|c|c|c|c|}
\hline Perlakuan & $2 \mathrm{mst}$ & $3 \mathrm{mst}$ & $4 \mathrm{mst}$ & $\begin{array}{c}5 \\
\text { mst }\end{array}$ & $6 \mathrm{mst}$ & $7 \mathrm{mst}$ & $8 \mathrm{mst}$ & $9 \mathrm{mst}$ & $\begin{array}{c}10 \\
\text { mst }\end{array}$ \\
\hline $\begin{array}{l}\text { C0 (kontrol) } \\
\text { C1 (1 ml/96 }\end{array}$ & $6.64 b$ & $10,1 b$ & $14.3 b$ & $21.8 \mathrm{a}$ & $26.355 b$ & $32.62 d$ & $36.9 \mathrm{e}$ & $45.43 \mathrm{~d}$ & $52.3 \mathrm{c}$ \\
\hline $\begin{array}{l}\mathrm{ml}) \\
\mathrm{C} 2(2 \mathrm{ml} / 96\end{array}$ & $9.4 \mathrm{a}$ & $12.2 \mathrm{a}$ & $17.6 \mathrm{a}$ & $24,1 \mathrm{a}$ & $29.36 \mathrm{a}$ & $37.7 \mathrm{a}$ & $43.82 \mathrm{c}$ & $50.79 \mathrm{~b}$ & $56.4 \mathrm{a}$ \\
\hline $\begin{array}{l}\mathrm{ml}) \\
\mathrm{C} 3(3 \mathrm{ml} / 96\end{array}$ & $10.6 \mathrm{a}$ & $13.8 \mathrm{a}$ & $19 a$ & $25.1 \mathrm{~b}$ & $30.9 \mathrm{a}$ & $40.28 b$ & $47.66 \mathrm{a}$ & $54.01 \mathrm{a}$ & $58.86 \mathrm{a}$ \\
\hline $\mathrm{ml})$ & $12,33 \mathrm{a}$ & $15.77 \mathrm{a}$ & $21.51 \mathrm{a}$ & $28.2 \mathrm{~b}$ & $32.66 \mathrm{a}$ & $43.04 \mathrm{~b}$ & $49.57 \mathrm{a}$ & $56.19 \mathrm{a}$ & $61.26 \mathrm{a}$ \\
\hline
\end{tabular}

*Angka yang diikuti oleh huruf yang sama menunjukkan berbeda tidak nyata

Tabel 2. menunjukkan, rata-rata pertambahan tinggi tanaman kontrol (C0) berbeda nyata dengan $\mathrm{C} 1, \mathrm{C} 2$, dan C3 semenjak minggu kedua. Sementara itu, diantar pupuk "BC" terdapat perberbedaan tidak nyata pada pertambahan tinggi tanaman mulai $2 \mathrm{mst}$ sampai $6 \mathrm{mst}$. Perbedaan nyata terjadi pada 7 mst sampai dengan 10 mst pada perlakuan kontrol. Diantar perlakuan konsentrasi "BC" terdapat perbedaan nyata rata-rata pertumbuhan kentang pada $8 \mathrm{mst}$ sampai $10 \mathrm{mst}$.

\section{Berat Umbi}

Hasil analisis sidik ragam pengaruh jenis pupuk dan konsentrasi terhadap berat umbi ditampilkan menunjukkan, konsentrasi pupuk berpengaruh nyata terhadap berat umbi dengan nilai signifikan 0,049 lebih kecil dari 0,05 . Sementara itu, perlakuan jenis pupuk memberikan pengaruh yang tidak nyata terhadap berat umbi, dengan nilai signifikan 0,051, sedikit lebih besar dari 0,05 .

Untuk mengetahui perbedaan berbagai perlakuan konsentrasi terhadap berat umbi, dilakukan uji Duncan yang hasilnya dapat dilihat pada Tabel 3.

Tabel 3. Hasil Uji Duncan Pengaruh Konsentrasi Pupuk Terhadap Berat Umbi Kentang (g)

\begin{tabular}{cccccc}
\hline \multirow{2}{*}{ "BF” (B) } & \multicolumn{4}{c}{ "BC" $(\mathrm{C})$} & \multirow{2}{*}{ Average } \\
\cline { 2 - 5 } & $\mathrm{CO}$ & $\mathrm{C} 1$ & $\mathrm{C} 2$ & $\mathrm{C} 3$ & \\
\hline B0 & 361,3 & 273,3 & 290,3 & 361,9 & $321,7 \mathrm{a}$ \\
B1 & 207,7 & 290,0 & 306,3 & 377,4 & $295,3 \mathrm{a}$ \\
B2 & 303,9 & 336,1 & 370,8 & 432,7 & $360,9 \mathrm{a}$
\end{tabular}




\begin{tabular}{|c|c|c|c|}
\hline B3 & 341,9 & 401,7 & $393,4 a$ \\
\hline RATA-RATA & $301,5 b$ & $342,3 b$ & $417,2 \mathrm{a}$ \\
\hline \multicolumn{4}{|c|}{ *Angka yang diikuti oleh huruf yang sama menunjukkan berbeda tidak nyata } \\
\hline \multicolumn{3}{|c|}{$\begin{array}{l}\text { Tabel } 3 \text { menunjukkan, rata-rata } \\
\text { berat umbi pada perlakuan C0 berbeda } \\
\text { tidak nyata dengan C1 dan C2, namun } \\
\text { berbeda nyata dengan C3. Lebih lanjut, } \\
\text { rata-rata berat umbi pengaruh pupuk } \\
\text { "BF" kontrol (B0) berbeda tidak nyata } \\
\text { Tabel 4. Hasil Uji Duncan Pengaruh Kombinasi } \\
\text { Berat Umbi Kentang (g)/ Sample }\end{array}$} & $\begin{array}{l}\text { dengan B1, B2, dan B3. Pengar } \\
\text { kombinasi jenis pupuk di } \\
\text { konsentrasinya terhadap produk } \\
\text { sampel dapat dilihat pada Tabel } \\
\text { berikut ini } \\
\text { Konsentrasi dan Jenis Pupuk Terhada }\end{array}$ \\
\hline \multicolumn{4}{|l|}{ Average } \\
\hline \multicolumn{3}{|c|}{ Duncan $^{\mathbf{a}, \mathrm{b}}$} & \\
\hline Combination & $\mathrm{N}$ & Subset & Expl \\
\hline $\mathrm{B} 1 \mathrm{C} 0$ & 2 & 207,7 & $\mathrm{~d}$ \\
\hline B0C1 & 2 & 273,3 & $\mathrm{~cd}$ \\
\hline B1C1 & 2 & 290 & $\mathrm{~cd}$ \\
\hline B0C2 & 2 & 290,3 & $\mathrm{~cd}$ \\
\hline $\mathrm{B} 2 \mathrm{C} 0$ & 2 & 303,9 & $\mathrm{~cd}$ \\
\hline B1C2 & 2 & 306,3 & $\mathrm{~cd}$ \\
\hline B3C0 & 2 & 333,1 & $\mathrm{~cd}$ \\
\hline B2C1 & 2 & 336,1 & $\mathrm{~cd}$ \\
\hline B3C1 & 2 & 341,9 & $\mathrm{~cd}$ \\
\hline $\mathrm{B} 0 \mathrm{C} 0$ & 2 & 361,3 & $\mathrm{bc}$ \\
\hline B0C3 & 2 & 361,9 & $\mathrm{bc}$ \\
\hline B2C2 & 2 & 370,8 & $\mathrm{bc}$ \\
\hline B1C3 & 2 & 377,4 & $\mathrm{bc}$ \\
\hline B3C2 & 2 & 401,7 & $\mathrm{bc}$ \\
\hline B2C3 & 2 & 432,7 & $a b$ \\
\hline B3C3 & 2 & 496,8 & $\mathrm{a}$ \\
\hline
\end{tabular}

a. Means for groups in homogeneous subsets are displayed. Based on observed means. The error term is Mean Square(Error) $=3798,157$ Uses Harmonic Mean Sample Size $=$ 2,000. b. Alpha $=, 05$.

Tabel 4 menunjukkan kombinasi B3C3 menghasilkan berat kentang tertinggi $496.8 \mathrm{~g}$ per sample dan terendah ditemukan pada B1Co hanya 207,6 g. Perlakuan B3C3 (496.8 g) berbeda nyata dengan B3C1 (341,8 g), B0C1 (273.3 g), dan B1C0 (207,6 g), tetapi tidak berbeda nyata dengan $\mathrm{B} 2 \mathrm{C} 3$, B3C2, B1C3, B2C2, B0C3, dan B0C0. Semakin tinggi konsentrasi pupuk "BF" dan "BC", semakin besar berat umbi kentang yang dihasilkan, dan sebaliknya.

\section{Pembahasan}

Kalsium merupakan salah satu nutrisi esensial dan dianggap sebagai salah satu unsur terpenting untuk meningkatkan daya tahan tubuh tanaman (Datnoff et al, 2007). Kalsium mengubah beberapa hama dan penyakit resisten pada tanaman melalui pengaruhnya pada pola pertumbuhan anatomi, morfologi, dan komposisi kimia tanaman (Elizabeth Ngadze, dkk, 
2014). Kalsium juga berperan penting dalam pembentukan dinding sel (Demarty et al, 1984).

Umbi kentang memiliki kadar kalsium endogen yang kecil dibandingkan dengan bagian vegetatif lainnya (Simmons dan Kelling 1987). El-Beltagy et al. (2000) menemukan, peningkatan hasil umbi dengan penambahan kalsium pada level sedang. Gangguan fisiologis yang berhubungan dengan kalsium antara lain berupa penyerapan kalsium dan transportasi air yang buruk ke organ dan tingkat transpirasi yang rendah (Kempen 2012). Gangguan fisiologis seperti umbi berlubang dan bercak coklat internal sangat memengaruhi kualitas umbi kentang dan hal tersebut erat kaitannya dengan kandungan kalsium pada tanaman. Kerentanan pasca-panen umbi terhadap patogen pembusuk juga berkaitan dengan komposisi kalsium pada umbi (Locascio et al. 1991).

Hasil penelitian ini, menunjukkan perlakuan konsentrasi kalsium berpengaruh terhadap tinggi tanaman, sedangkan jenis pupuk dan interaksi antara jenis pupuk dan konsentrasi tidak berpengaruh nyata. Hal tersebut artinya kedua jenis pupuk ("BF" dan "BC") boleh tidak digunakan bersamaan atau diaplikasikan secara terpisah. Yang paling penting untuk diperhatikan adalah konsentrasi kedua jenis pupuk untuk memperoleh hasil kentang yang maksimal. Hasil penelitian ini memperlihatkan konsentrasi B2C2, $\mathrm{B} 3 \mathrm{C} 2, \mathrm{~B} 2 \mathrm{C} 3$, dan $\mathrm{B} 3 \mathrm{C} 3$ menghasilkan pertumbuhan tinggi rata-rata $35.7 \mathrm{~cm}$, $36.8 \mathrm{~cm}, 38.6 \mathrm{~cm}$, dan $39.5 \mathrm{~cm}$. Peningkatan pertumbuhan tinggi tanaman hasil penelitian ini menujukkan, pupuk "BF" maupun "BC" memberikan pengaruh positif. Hal tersebut sesuai dengan Anonim (2018) yang menyebutkan pupuk "BF" maupun "BC" memiliki kandungan kalsium yang tinggi.

Easterwood. G. W (2002), menyatakan unsur kalsium berfungsi untuk memperkuat dan mempertebal dinding sel tanaman, dan merupakan bagian terpenting dari dinding sel sehingga menghasilkan struktur tubuh tanaman yang kuat dengan mempercepat pertumbuhan tanaman, pertumbuhan bunga dan buah, dan juga mutu produksi buah. Kalsium adalah salah satu nutrisi tanaman penting dan melakukan peran penting dalam struktur dan fungsi membran tanaman dimana kalsium berkontribusi terhadap pemeliharaan stabilitas membran sel dan struktur dinding (Marschner 1995). Karenanya kalsium meningkatkan resistensi jaringan tanaman terhadap stress biotik dan abiotik (Ilyama et al. 1994). Palta (1996) melaporkan, peran kalsium untuk mengikat gugus fosfat dan karboksilat fosfolipid pada permukaan membran membantu meningkatkan stabilitas membran sel. Marschner (1995), tanaman yang menerima kalsium dalam jumlah besar selama pertumbuhan mengandung bahan pektik tinggi seperti kalsium pekat. Harris (1992) menegaskan, kalsium juga membantu tanaman beradaptasi dengan stres dengan membentuk peringatan ketika stress terjadi, ini memiliki peran penting dalam mengatur transportasi aktif $\mathrm{K}$ untuk pembukaan stomata, dan sangat penting dalam membantu stress pada musim panas, sehingga menurunkan layu. Kalsium juga mendorong perkembangan akar dan pertumbuhan tanaman karena terlibat dalam pemanjangan akar dan pembelahan sel (Ilyama et al. 1994). Clarkson (1984) menemukan adanya penurunan insiden bintik coklat internal dan nekrosis. Menurut Harris (1992) kadar kalsium yang tinggi dalam umbi menurunkan risiko memar saat panen dan transportasi berikutnya.

Nasren dan Abdelhady (2015), melakukan penelitian di daerah Deta Nile, Mesir, untuk mengetahui efek kalsium dan potasium pada pertumbuhan dan hasil tanaman kentang dan menemukan bahwa rata-rata jumlah 
cabang yaitu 4,67 dan terendah 3,33. Parman (2007) melakukan penelitian tanaman kentang dengan menggunakan pupuk organik cair dan memperoleh hasil pertumbuhan tinggi tanaman maksimal yaitu $47,18 \mathrm{~cm}$ dan terendah yaitu $41,36 \mathrm{~cm}$. Lebih lanjut disebutkan penambahan tinggi tanaman mula-mula lambat, kemudian berangsur-angsur menjadi lebih cepat sampai tercapai suatu laju pemanjangan batang yang maksimum yaitu pada minggu kedelapan yang akhirnya laju pemanjangan batang konstan hingga minggu kesebelas. Suripto W, dkk (2018) melakukan penelitian tanaman kentang kleci dengan menggunakan pupuk organik cair sabut kelapa dan menemukan bahwa tinggi maksimum tanaman kentang yaitu $24,14 \mathrm{~cm}$ dan tinggi tanaman yang terendah yaitu $21,80 \mathrm{~cm}$.

Flego et al (1997), melaporkan efek kalsium pada peningkatan daya tahan kentang melawan patogen di akar. Lebih lanjut Ngadze (2014), dalam penelitian nya di Zimbabwe menemukan bahwa kalsium berperan signifikan dalam meningkatkan asam caffeic dan klorogenik yang merupakan bahan anti mikroba pada tanaman kentang. Hasil penelitian ini menunjukkan, pertumbuhan tinggi tanaman kentang terbesar ditunjukkan oleh B3C3 yaitu 39,5 dan terkecil B0C0 sebesar 23,2. Perbedaan hasil penelitian ini dengan yang dilakukan oleh Parman (2007) dan Suripto W, dkk (2018) lebih disebabkan karena jenis pupuk cair dan jenis kentang yang berbeda. Pupuk "BF" dan "BC" tidak termasuk kategori pupuk organik, sementara itu baik Parman (2007) maupun Suripto W, dkk (2018) keduanya menggunakan pupuk organik cair.

Ketinggian terendah tanaman kentang hasil penelitian Parman (2007) yaitu $41,36 \mathrm{~cm}$ hampir sama dengan perlakuan B3C3 ("BF" 7,5 ml/L x "BC" $3 \mathrm{ml} / 96 \mathrm{ml}$ ) hasil penelitian ini yaitu $39,5 \mathrm{~cm}$. Lebih lanjut, ditemukan bahwa perlakuan B0C1 ("BF" $0 \mathrm{ml} \mathrm{x}$ "BC" 1 $\mathrm{ml} / 96 \mathrm{ml}$ ) menghasilkan pertumbuhan rata-rata tinggi tanaman $25,5 \mathrm{~cm}$, hampir sama dengan tinggi maksimum yang dihasilkan oleh Suripto, dkk (2018) yaitu $24,14 \mathrm{~cm}$. Hasil penelitian ini membuktikan bahwa pupuk kalsium "BF" dan "BC" dapat digunakan untuk budidaya tanaman kentang termasuk untuk mempercepat pertumbuhan.

Nasren dan A Abdelhady (2015), melakukan penelitian di daerah Deta Nile, Mesir, untuk mengetahui efek kalsium dan potasium pada pertumbuhan dan hasil tanaman kentang dan menemukan bahwa rata-rata berat umbi yaitu $158,70 \mathrm{~g}$ dan terendah 124,87 g. Karamina \& Fikrinda (2016) melakukan penelitian tanaman kentang dengan menggunakan pupuk cair organik, diperoleh hasil berat umbi tertinggi 725,77 g, dan terendah 77,93 g. Wissem, dkk (2015), berat umbi elemen penting lain dari kualitas kentang adalah berat umbi. Umbi dipanen 90 hari setelah tanam. Saat panen, umbi-umbian dari masing-masing plot dibersihkan, ditimbang per sampel dan dicatat datanya. Efek penambahan kalsium nitrat pada berat umbi kentang menunjukkan bahwa kalsium efektif dalam meningkatkan berat umbi ratarata. Persentase bahan kering dalam umbi berkisar antara 120 hingga $184 \mathrm{~g}$. Berat tertinggi ditemukan pada tanaman yang diberi kalsium tingkat tinggi, dan sebaliknya bobot umbi yang paling sedikit ditemukan di petak kontrol (T1). Lebih lanjut, produksi berat umbi menggunakan pupuk kalsium nitrat juga berbeda, meningkat secara signifikan ( $\mathrm{P}$ $\leq 0,01$ ) di atas kontrol (T1) dan perbedaan di sini secara signifikan $(\mathrm{P} \leq$ 0,01 ) ditemukan pada suatu perlakuan dibandingkan dengan peerlakuan lainnya.

Hasil penelitian ini (Gambar 4) memperlihatkan berat tertinggi pada perlakuan B3C3 yaitu 496,8 g dan terendah pada perlakuan B1C0 yaitu 207,7 g. Lebih lanjut menunjukkan, 
pupuk "BC" menghasilkan umbi kentang dengan berat yang lebih tinggi dan pupuk "BF" sebaiknya. Berat umbi berbanding lurus dengan pengaruh pupuk "BC" dan pupuk "BF" menghasilkan umbi lebih banyak dengan ukuran yang relative kecil dan sebaliknya pupuk "BC" menghasilkan umbi relative tidak banyak tetapi berukuran besar.

\section{Kesimpulan}

1. Rata-rata pertumbuhan tinggi tanaman pengaruh pupuk ' $\mathrm{B}$ ' pada 10 mst tertinggi adalah $\mathrm{B} 3(60,28$ $\mathrm{cm})$, berbeda nyata dengan B0 $(51.73 \mathrm{~cm})$, tetapi berbeda tidak nyata dengan B2 $(60.25 \mathrm{~cm}), \mathrm{B} 1$ $(58.45 \mathrm{~cm})$.

2. Pengaruh pupuk ' $\mathrm{C}$ ' pada ketinggian tanaman ditemukan, pada $10 \mathrm{mst}$ rata-rata tinggi tanaman pada $\mathrm{C} 3$ adalah $61,26 \mathrm{~cm}$, berbeda nyata dengan $\mathrm{C} 0(52,3 \mathrm{~cm})$, tetapi tidak berbeda nyata dengan $\mathrm{C} 1(56,4 \mathrm{~cm})$, dan C2 $(58,86 \mathrm{~cm})$

3. Konsentrasi pupuk cair kalsium "BF" (B) berpengaruh nyata terhadap pertumbuhan dan produksi tanaman kentang. Pada parameter tinggi tanaman, hasil tertinggi ditemukan pada B3 yaitu 7,5 ml/96 $\mathrm{ml}$ air dan terendah B0 (kontrol). Berat umbi tertinggi terdapat pada B3, 7,5 ml/96 ml air dan terendah $\mathrm{B} 1, \quad 2,5 \mathrm{ml} / 96 \mathrm{ml}$ air. Ukuran diameter umbi tertinggi pada B1 $(2,5 \mathrm{ml} / 96 \mathrm{ml}$ air $)<3 \mathrm{~cm}$ dan terendah B0 (kontrol).

\section{Ucapan Terimakasih}

Penelitian ini tidak akan terlaksana tanpa adanya dukungan pendanaan dari PT. Bingei Agung Medan, oleh karena itu penulis menyampaikan terimakasih kepada $\mathrm{CO}$ dan Direktur PT. Bingei Agung Medan. Terimakasih juga disampaikan kepada Dr. Meriksa Sembiring, A. Lubis dan R. br Hasibuan, dan Rektor Universitas Quality, Ibu Prof. Dr. Erna Frida, M.Si.

\section{Daftar Pustaka}

Bangerth F. 1979. Calcium-related physiological disorders of plants. Annual

97-122

Review of Phytopathology 17:

Burton, WG 1989, The potato, Ed 3, Longman Scientific \& Technical, UK.

Cholil, A dan Latief Abadi. 1991. Penyakit-penyakit penting tanaman pangan. Pendidikan Program Diploma Satu Pengendalian Hama Terpadu. Fakultas Pertanian Universitas Brawijaya Malang.

Clarkson DT. 1984. Calcium transport between tissues and its distribution in the 449-456.

plant. Plant Cell Environment 7:

Datnoff, L.E., Elmer, W.H., Huber, D.M., 2007. Mineral Nutrition and Plant Disease. APS Press, Minnesota.

Dekkers, TBM \& Avander weff. I. 2001. Mutualistic functioning of indigenous arbuscular mycorhizae in spiring barley and winter wheat after cessation of long team phosphate fertilization. Mycorrhiza. vol. 10, pp.195-201.

Demarty, M., Morvan, C., Thellier, M.B., 1984. Calcium and the cell wall. Plant

Cell Environ. 7, 441e448.

Diny Djuariah, Tri Handayani, dan Eri

Sofiari. 2017. Toleransi

Tanaman Kentang (Solanum tuberosum) Terhadap Suhu Tinggi Berdasarkan Kemampuan Berproduksidi Dataran Medium. J. Hort. Vol. 27 No. 1, pg : 1- 10

Dubey RK, Singh V, Devi K, Kartek K. 2013. Response of calcium application on yield and skin damage of potato 
tubers. Indian Journal of Horticulture 70: 383-386

Easterwood. G.W. 2002. Calcium's Role In PlantNutrition. Fluid Journal, pg 1-3.

Effendi. BH. 2004. Pupuk dan Pemupukan. Universitas Sumatera Utara Fakultas Pertanian. Medan.

El-Beltagy MS, Abou-Hadid AF, ElAbd SO, Singer SM, Abdel-Naby A. 2000 .

Response of fall season potato crop to different calcium levels. In: II Balkan Symposium on Vegetables and Potatoes 579: 289-293.

Elizabeth Ngadzea, Teresa A. Coutinhoa, David Icishahayob, Jacquie E. van der

Waalsa. 2014. Effect of calcium soil amendments on phenolic compounds and soft rot resistance in potato tubers. Crop Protection.

Fernie, AR \& Willmitzer, L 2001, 'Molecular and biochemical triggers of potato

tuber development', Plant Physiology, vol. 127, pp. 1459-65.

Fisher, N. M. dan P. R. Goldsworthy. 1992. Fisiologi Tanaman Budidaya. Penerbit UI - Press. Jakarta

Flego, D., Pirhonen, M., Saarilahti, H., Palva, T.K., Palva, E.T., 1997. Control of

virulence gene expression by plant calcium in the phytopathogen Erwinia carotovora. Mol. Microbiol. 25, 831e838.

Hanolo, W. 1997. Tanggapan tanaman selada dan sawi terhadap konsentrasi dan cara pemberian pupuk cair stimulant. J. Agrotropika. vol. 1, no. 1, hlm. 25-9.

Harris, EM. 1978. The potato crop - The scientific basis for improvement.

Chapman and Hall, London.

Harris PM. 1992. Mineral nutrition. In
The potato crop 162-213.

Hendro Sunarjono. 2007. Petunjuk Praktis Budidaya Kentang. AgroMedia Pustaka. Jakarta.

Hendrinova. 1990. Pengaruh Berbagai Pupuk Organik dan Pupuk Daun terhadap Pertumbuhan dan Hasil Rimpang Jahe. Jurusan Budidaya Pertanian Fakultas Pertanian IPB. Bogor

Herman. 2000. Peranan dan prospek pengembangan komoditas kakao dalam perekonomian regional Sulawesi Selatan. Warta Pusat Penelitian Kopi dan Kakao Indonesia. vol. 16, no. 1 , hlm. $21-31$.

Hijmans, RJ 2003, 'The effect of climate change on global potato production', Amer J of Potato Res, vol. 80, pp. 271-80.

Hooker WJ. 1981. Compendium of potato diseases (Vol. 8). International Potato Center.

Islami T dan Utomo. 2005. Hubungan Tanah, Air dan Tanaman. IKIP Semarang Press. Semarang.

Karamina, H. · W. Fikrinda. 2016. Aplikasi pupuk organik cair pada tanaman kentang varietas granola di dataran medium. Jurnal Kultivasi Vol. 15(3), pg : 154-158.

Karlsson BH, Palta JP. 2002. Enhancing tuber calcium by in-season calcium application can reduce tuber bruising during mechanical harvest. In: XXVI International Horticultural Congress: Potatoes, Healthy Food for Humanity: International Developments in Breeding, 619: 285-291.

Katayama, Katsumi, dan Teramoto, Takeshi. 1997. Seed Potato Production and Control of Insect Pest and Diseases in Indonesia, dalam Agrochemicals Japan Journal. Japan-Plant Protection.

.Kempen E. 2012. The relationship 
between internal brown spot and the calcium content of tubers.

Kirkby EA, Pilbeam DJ. 1984. Calcium as a plant nutrient. Plant, Cell \& Environment 7: 397405.

Kleinhenz MD, Palta JP. 2002. Root zone calcium modulates the response of potato plants to heat stress. Physiologia plantarum 115: 111-8

Kotak, S, Larkindale, J, Lee, U, Do ring, PvK, Vierling, E \& Scharf, K-D 2007, 'Complexity of the heat stress response in plants', Curr.Opin. Plant Biol., vol. 10, pp. 310-6.

Kratzke MG, Palta JP. 1985. Evidence for the existence of functional roots on potato tubers and stolons: Significance of water transport to the tubers. American Potato Journal 62: 227-236. 